\title{
Enzyme Immunoassay Unit
}

National Cancer Institute

\section{Source}

National Cancer Institute. Enzyme Immunoassay Unit. NCI Thesaurus. Code C122205.

A unit for measuring concentration or/and reactivity of a test substance (an antigen or antibody of interest) as defined in the literature reference standard for the particular quantitative enzyme immunoassay method. 